\title{
Muzykanci z Bremy albo zwierzoczłekoświat
}

Town Musicians of Bremen

\author{
||Joanna Maleszyńska
}

\begin{abstract}
The classic Brother Grimm fairy tale is a story about animals - not human issues, but the animals themselves. A donkey, a dog, a cat and a rooster do not stand for humans or human types, but they are independent subjects. Their anthropomorphic treatment does not serve to illuminate purely "human" issues, but rather allows the leader or listener to find empathy towards our lesser brothers. The music the animals play is a catalyst for their liberation. The old and slaughterhouse-bound escape not only to the town of Bremen, but into the saving realm of art. Solidarity and harmony, agreement and collaboration - that is what the amateur animal musical quartet represents, and the lesson they impart to, often pragmatic and uncaring humans, is how to be good.
\end{abstract}

Key words: Animals, senility, music, harmony, empathy

Streszczenie: Klasyczna baśń braci Grimm jest opowieścią o zwierzętach; nie o problemach ludzi, ale o zwierzętach samych. Osioł, pies, kot i kogut nie są tu potraktowane jako figury ludzi, ludzkie typy i reprezentacje, lecz jako samodzielne podmioty. Antropomorfizacja zaś nie służy ukazaniu i oświetleniu spraw czysto „ludzkich”, lecz pomaga czytelnikowi i słuchaczowi empatycznie odnieść się do sytuacji braci mniejszych. Muzyka, której uprawiania podejmują się zwierzęta, jest katalizatorem ich wyzwolenia. Stare i przeznaczone na rzeź uciekają nie tylko do Bremy, ale i w przestrzeń ocalającej sztuki. Solidarność i harmonia, zgoda i współpraca - oto co reprezentuje kwartet zwierzęcych, amatorskich muzyków. Uczą one, jak być dobrym dla pragmatycznych i często nieczułych ludzi.

Słowa kluczowe: zwierzęta, starość, muzyka, zgoda, empatia

I jak to jest, że człowiek wychowany wśród (...) przyjaznych delegatów królestwa przyrody, kiedy dorośnie, niszczy ją beztrosko, strzela, ogłusza, zarzyna i, zaiste, „chłop żywemu nie przepuści”? Tym samym, jakby zakreślał granicę pomiędzy przyrodą uczłowieczoną, tą na niby, i przyrodą prawdziwą, która jest mu obca, i której jest obcy (Miłosz 1994, 23). 
Zwierzęcy bohaterowie baśni braci Grimm nie są specjalnie dobrze dobrani: to osioł, pies, kot i kogut. Mamy więc trzy ssaki i ptaka, żyjące według różnych obyczajów zwierzęcych i wywodzące się z różnych systematyk. Wspólnota, którą tworzą, wynika nie z porządku natury, ale z uwarunkowań kulturowych; łączy je służba u gospodarza Georga - osioł pełni funkcję tragarza (jest zwierzęciem pociągowym), pies pilnuje obejścia, kot łapie myszy, a kogut rządzi w kurniku. Problem w tym, że wszystkie one są stare, nie mają już sił, by pracować dla ludzi, więc obowiązki przeznaczone im w gospodarstwie coraz częściej pozostają nietknięte. Osioł jest zmęczony i często odmawia współpracy z Georgiem; pies bardzo słabo widzi i niedosłyszy, nie jest w stanie rozpoznać przybysza i odróżnić go od domownika, zatem zadania „obronne” lub choćby komunikujące zagrożenie wypełnia kiepsko; kot stracił swoją umiejętność łowienia, nie czuje już zapachu myszy i nie potrafi skutecznie ich łapać, a kogut - cóż, kury śmieją się z niego i nie ustawiają się w kolejce, by mieć z nim wspólne jajko... Zwierzęta w baśni Grimmów silniej niż więzy gatunkowe łączy i upodabnia to, że wszystkie są stare. W okrutnie racjonalnym świecie chłopskiej logiki, pozbawionej sentymentów i współczucia, kiedy zwierzę przestaje być pomocne w podwórzu czy na polu - musi zostać usunięte ${ }^{1}$. Jest traktowane jak maszyna rolnicza, narzędzie pracy, utensylium; żaden tam domownik i najbliższy przyjaciel człowieka. Co najwyżej - towar do sprzedania rakarzowi (osioł) lub przyszła karma dla świń (pies), potencjalny futrzany okład na bolące korzonki (kot) lub rosół na niedzielny stół (kogut).

Baśniowość świata Grimmów nie przejawia się głównie w samej fabule czy w konstrukcji rzeczywistości przedstawionej; ta jest racjonalna i, wypada sądzić, wręcz dokumentalna (baśń Muzykanci z miasta Bremy powstała, a raczej została w swym „najbardziej pierwotnym kształcie” zapisana przez autorów w początkach XIX wieku, ale prezentuje uniwersalny dla chłopstwa niemieckiego, i w ogóle - europejskiego, sposób myślenia o zwierzętach, zapewne niezmieniony od rozpoczęcia procesu udomowienia aż, właściwie, do dziś). Ze świata fantastyki pochodzi w tej opowieści przede wszystkim co innego: kreacja narratora - jest nim osioł - oraz pozostałych bohaterów zwierzęcych przez przypisanie im umiejętności myślenia w ludzkich kategoriach, mówienia, posiadania instynktu moralnego i zdolności artystycznych. Od początku baśni wiemy, że dzięki tym walorom zwierzęta - wspaniała czwórka przyjaciół - będą miały wpływ na rozwój wypadków, i trochę specjalnie, a trochę przypadkowo poprowadzą intrygę na swój sposób.

${ }^{1}$ O stosunku wiejskich społeczności do ludzi starych i biednych (Pawełczyk 2013; Kaźmierczak 2013). O okrucieństwie w samych baśniach braci Grimm ostatnio pisali autorzy tomu, będącego pokłosiem konferencji naukowej w Uniwersytecie Warszawskim. Zob. Grimm: potega dwóch braci. Kulturowe konteksty „Kinder - Und Hausmärchen”, Kostecka W. (red.), (szczególnie: Skrzypczak M., Unurzane w smacznym okrucieństwie. Estetyka groteski i makabreski w wybranych baśniach braci Grimm oraz Kostecka W., Od aksjologii do estetyki. Grimmowskie ujęcia grozy i okrucieństwa w „Kinder - Und Hausmärchen” jako inspiracja dla twórców współczesnej fantastyki). 
Przede wszystkim rozumieją one ludzką mowę, a szczęśliwie gospodarz Georg i jego druga żona Marta nic o tym nie wiedzą. To ludzie, którzy traktują zwierzęta domowe „pragmatycznie”, zapewne dość bezwzględnie i całkiem użytkowo; po chłopsku, by tak rzec. Zakochana w parobku Johannie pasierbica gospodyni, Lizzy - dzięki swej młodości, bezinteresowności, a także zapewne wolą charakteryzujących ją autorów - lubi osła, rozmawia z psem, głaszcze kota i nie przegania starego koguta; podobnie czyni szczery i szczerze w Lizzy zakochany Johann. Młodzi nie tylko pojmują mowę zwierząt (dziwnie podobną do języka ludzi; w Muzykantach z Bremy zwierzęta mówią po niemiecku...), ale potrafią też porozmawiać z nimi, dowiedzieć się czegoś, umówić się na dalsze działania czy poprosić o przysługę i - podziękować za nią.

Z pewnością ludzie zawsze byli wrażliwi na piękno przyrody, gór, lasów, jezior, morza, wschodów i zachodów słońca. Ale do mieszkających tam stworzeń mieli stosunek użytkowy. Nie jestem pewien, czy ładny zwyczaj u niektórych plemion syberyjskich - przebłagiwanie duszy niedźwiedzia po tym, kiedy się go zabiło miał źródła w szacunku dla życia czy w obawie, że po śmierci będzie szkodzić (Miłosz 1994, 23).

Fabuła opowieści jest prosta: Marta, chciwa macocha, chce wydać bogato za mąż za sąsiada, Hansa, swoją pasierbicę Lizzy i - przy biernej postawie gospodarza Georga - wyekspediować parobka Johanna tak daleko, by dziewczyna o miłym jak najszybciej zapomniała. Najlepiej do Bremy, gdzie w porcie brat Marty weźmie chłopaka na okręt i sprawi, że ten na rok zniknie Lizzy z oczu. Jednak te niecne plany poznają stare, ale wciąż bystre zwierzęta, i postanawiają działać.

Tytułowi bohaterowie baśni ani nie są muzykantami, ani nie pochodzą z Bremy! Pomysł, aby muzykowaniem, grą lub śpiewem zacząć zarabiać na życie i dzięki temu nie zginąć w wielkim świecie z głodu, przychodzi na myśl „siwogłowemu” osłowi. Kiedy przypadkiem usłyszy, że wiecznie coś knująca Marta chce go sprzedać na kiełbasy, psa dać w postaci mielonki na pokarm świniom, kota obedrzeć ze skóry, a koguta ugotować zaczyna obmyślać plan ratunkowy. Ponieważ właśnie odszedł zmuszony do tego szantażem Johann, czwórka zwierząt wyrusza jego tropem w stronę Bremy, w której osioł już kiedyś był z gospodarzem i pamięta, że idzie się tam dwa dni. Pies, kot i kogut z ociąganiem opuszczają swój dotychczasowy dom i obejście - w samą porę! Gospodarz właśnie naostrzył siekierę i już, poganiany przez żonę, chce przystąpić do rzezi. Ze stodoły, w której uwięziła ją macocha, wyswobadza się sprytna Lizzy i podąża - instynktownie w dobrym kierunku - za ukochanym i za przyjaznymi zwierzakami.

Pozytywni bohaterowie baśni wyruszają w świat pod przymusem: Johann z obawy, by chlebodawczyni nie skrzywdziła Lizzy, zwierzęta - by nie zostać zgładzone, Lizzy - by ratować się przed niechcianym zamęściem z zasobnym, ale niekochanym sąsiadem. Brema jest dla nich wszystkich miejscem zesłania, nieznanym, obcym miastem, w którym będą musieli/mogli zacząć 
życie od nowa, od początku: młodzi tak, jak sobie tego życzą, bez ingerencji rodziców, biorąc pewnie kiedyś ślub i czerpiąc radość ze wzajemnej miłości, zwierzęta uciekając przed starością i śmiercią - w sztukę. To myślenie życzeniowe, które jednak zamieni się w końcu w konkret.

Zanim to nastąpi, wszystkich uciekinierów spotkają mrożące krew w żyłach przygody, niespodziewane i straszne: Johanna pojmają leśni zbójcy i w swojej kwaterze każą mu usługiwać do stołu oraz pracować ponad siły, zwierzęta zaś uciekną czyhającemu na nie rakarzowi. Traf chce, że nasza czwórka, która podczas popasu rozpoczęła już próbę, spotyka Lizzy i razem z nią podchodzi w pobliże zbójeckiej chaty. Debiutujący artyści trenują swoje możliwości wokalne, które okażą się istotnie żenująco słabe. Stojąc jeden na drugim, na wzór piramidy, zaglądają też przez okno domu, by sprawdzić, kto jest we wnętrzu, i robią to akurat wtedy, gdy jeden z rabusiów opowiada kamratom historię o Herbercie Okrutnym. Był to zbój nad zbóje, który za swoje podłe czyny tuła się teraz, już pośmiertnie, między niebem a ziemią. Nawiedza czasem, jako memento i przestroga, swoich kolegów po fachu, objawiając swoją obecność strasznym, zwiastującym nieszczęście, krzykiem i wyciem...

Kiedy w „opowieści wewnętrznej” padają te słowa, słuchający jej zbójcy zauważają za oknem dziwny, widmowy kształt, słabo zarysowany w ciemnościach nocy; to pies, kot i kogut stanęły kolejno na sobie i na ośle, aby według własnych, najlepszych intencji - „zmiękczyć” śpiewem serca ludzi, którzy tam pewnie mieszkają, i którzy zapewne ujęci chóralnym występem wędrowców dadzą im jakąś strawę i udzielą na noc schronienia. Pieśń powstała w zwierzęcych gardłach ma bardzo wątpliwe walory artystyczne; to pozbawiony harmonii katzenjammer, muzyka kocia albo raczej kocio-psio-oślo-kurza (kogucia), nieskładna, nieczysto wykonana, jazgotliwa i w efekcie przerażająca. Rabusie są przekonani, że pod ich oknem stanął sam Herbert Okrutny! Prawdziwie wystraszeni - w końcu objawił im się upiór „z branży”, sławny zbój, którego losy są przestrogą dla złodziei, tradycyjnie bardzo przesądnych - uciekają do lasu mimo głębokiej nocy, zimna i kompletnych ciemności. Taką moc ma śpiew! Cóż, że fałszywy, niestrojny, dla ucha ludzkiego nieznośny. Choć wzniecony był z intencją łagodną i serdeczną, wywołał skutek przeciwny do zamierzonego, ale w efekcie pozytywny i wieloraki. Zbójników przeraził, Johanna ocalił, czytelników zaś i słuchaczy rozbawił, dał poczucie odprężenia i dokonującej się, mimochodem, sprawiedliwości.

A może przyroda domaga się od nas traktowania jej z humorem? Może Puchatek, Prosiaczek i Królik oraz krewni i znajomi Królika, może całe to uczłowieczenie jest tym, czego przyroda się po nas spodziewa? Inaczej mówiąc, może nic innego nie potrafimy o niej powiedzieć, poza wyposażeniem jej w smutek, uśmiech, ponurość, pogodę? (Miłosz 1994, 41). 
Wobec takiego, a nie innego przebiegu wydarzeń przybyli do lasu śladem zbiegów gospodarze - Marta i Georg - ulegają „perswazji” zbójców (którzy, mogąc znów grozić bronią i okradać wędrowców, odzyskują dawną werwę) i porzucają chęć rewanżu. Oddają też los „swoich” zwierząt w ręce Lizzy i Johanna; ci, dotarłszy do gościnnej Bremy, biorą wnet ślub, a na wesele zapraszają zaprzyjaźniony kwartet zwierzęcych muzykantów, teraz już śpiewających a nie wyjących, bo regularne ćwiczenia i niesłabnący zapał wykonawczy mogą zdziałać cuda. Można by zatem powtórzyć za Beaumarchais, który w 1784 roku przedstawił swoje arcydzielne Wesele Figara, że „wszystko kończy się piosenką" ${ }^{2}$. W jego intencji, jeśli jakakolwiek rzecz, w życiu czy w literaturze, „kończy się piosenką”, to znaczy, że kończy się dobrze. Radosny finał baśni nie jest może tak spektakularny, jak w wodewilowym zakończeniu słynnej francuskiej komedii, ale sakramentalne odautorskie (i odgatunkowe) „I żyli długo i szczęśliwie” jednak pada; nie tylko w odniesieniu do szczęśliwych nowożeńców, ale i w formie charakterystyki dalszych losów, teraz już bezpiecznych i spokojnych, Muzykantów z Bremy. Osioł, pies, kot i kogut dostają u Lizzy i Johanna dożywocie, w takim sensie, jak kiedyś rezydenci - dalsi, ubodzy krewni w posiadłościach swych zamożnych rodzin. Nic już nie muszą robić, nie pełnią straży i służby, przeciwnie - za wykonywaną całe życie ciężką pracę zyskują należną nagrodę: wygodną kwaterę, strawę i szacunek. A także, domyślamy się, swobodną możliwość uprawiania ukochanej sztuki, co - jak wiemy ze współczesnych badań - przedłuża amatorom życie, a zwierzęcych bohaterów z baśni Grimmów czyni jeszcze bardziej ludzkimi.

Od pokoleń uczono nas, że tylko człowiek ma duszę nieśmiertelną. Jeżeli dzisiaj trochę inaczej mówi się o linii oddzielającej nas od całej reszty istot żywych, nie znaczy to, że ta linia dla nas nie istnieje. Czujemy, że istnieje, i że, wyrażając się po staroświecku, przesądza o tym świadomość i wolna wola człowieka (Miłosz 1994, 35).

O konstytutywnych gatunkowych cechach baśni tak pisał Roger Caillois:

Baśniowość to świat cudowności, który łączy się ze światem rzeczywistym, nie naruszając w niczym jego wewnętrznego ładu i nie niszcząc jego spójności (...). Baśń dzieje się w świecie, w którym czasy są naturalne, a magia [jest] regułą. Pierwiastek nadprzyrodzony nie jest w nim straszny, nawet nie dziwny, bo stanowi on substancję tego świata, jego prawo, jego klimat. Nie wyłamuje się z żadnej normy; należy do porządku rzeczy. (...) Ten zaczarowany świat jest harmonijny, nie zna sprzeczności, pełen jest jednak przygód, bo i jemu nieobca jest walka ze złem (...). Ale skoro raz się przyjmie szczególne założenia tego nadprzyrodzonego świata, wszystko w nim pozostanie w godny uwagi sposób stabilne i jednorodne (Caillois 1967, 32-33).

${ }^{2}$ Warto przypomnieć, że w śpiewanym (i tańczonym) zakończeniu Wesela Figara pamiętną kwestię o piosence wykonuje sędzia o nazwisku Don Guzman Gąska. Jest on opisany przez autora jako głupiec, w którym spotyka się kontrastowo „powaga stanowiska” ze „śmiesznością charakteru”, co daje niezawodny efekt komiczny. Sędzia Guzman, postać schematyczna, raczej typ niż osoba, jest głupi i zarozumiały jak gęś (symbolizująca w kulturze europejskiej te przywary), ale i jego w finale obejmie wszechwładne w tej sztuce przebaczenie, płynące od widzów i od samego autora (Beaumarchais $1951,51,235)$. 
Baśniowy model świata rządzi się własnymi prawami: niektóre z nich np. prawo wynikania czy prawo przyczynowości - wzięte są z systemu zasad realnie istniejącego świata (tyle że na gruncie baśniowym konsekwentniej się ich przestrzega). Inne, jak obdarzanie nie-ludzkich istot zdolnością rozumienia i używania człowieczej mowy czy też prawo „dobrego zakończenia" - są przynależne tylko fikcyjnej rzeczywistości personifikowanych roślin i zwierząt. Kreacja świata przedstawionego, zgodna z zasadami fantastyki baśniowej, pozwala odbiorcy bez problemu i bez poczucia dysonansu poznawczego zaakceptować elementy cudów, magii i niezwykłości. Mówiące i czujące zwierzęta nie wzbudzą w czytelniku czy słuchaczu niepokoju ${ }^{3}$.

Bohaterowie Muzykantów z Bremy nie są poglądowo ukazanymi „typami” ludzkimi; zachowują swoje indywidualne, i choć nieskomplikowane, to wyraziste cechy osobowe, tylko częściowo wywiedzione z przypisywanych im od wieków znaczeń symbolicznych. Muzykanci Grimmów to - powtórzmy - osioł, pies, kot i kogut; w bajce alegoryczno-moralizatorskiej symbolizowaliby kolejno: głupotę, wierność, fałsz i odwagę. Głupi osioł z wiernym psem wędrują w towarzystwie fałszywego kota i odważnego koguta? Chyba jednak nie; podobnie nie tłumaczy nam niczego w baśniowej opowieści chrześcijańska symbolika tych zwierząt, według której pewne „zoologiczne” atrybuty odsyłają do konkretnych świętych (np. osioł to św. Herman a kogut - św. Piotr). Nasi muzykanci są - ni mniej, ni więcej - tylko uczłowieczonymi - w znaczeniu: odczuwającymi, obdarzonymi wrażliwością, wyobraźnią i artystycznym talentem - istotami; o s o b a mi . Nie wskazują na - leniwych, radosnych, głupich czy sprytnych - ludzi; nie. Odkrywają, często nieznane wiedzy potocznej, a prawdopodobne możliwości własne, istotowe, immanentne; kreują uniwersum naszych „mniejszych braci", którzy być może nie tylko w Wigilię Bożego Narodzenia rozmawiają, wróżąc słyszącemu je człowiekowi przyszły los.

Istotnym rysem opowieści o zwierzęcych muzykantach jest też to, że stanowią oni zbiorowość (przy zachowaniu podmiotowości jednostek) oraz zespół, i to w dwojakim znaczeniu. Mieszkańcy zagrody Georga są zespołem, bo w pracy u niego kontaktują się z sobą, dbają o siebie nawzajem, przyjaźnią się prawdziwie, a świadczy o tym obmyślany wspólnie i niepomijający nikogo plan ucieczki. Zespołowa ma być w założeniu, od samego początku, „działalność artystyczna” zwierząt; ponieważ są grupą, która stale się wspiera i zawsze może na siebie liczyć - po pewnym „dotarciu” może uda się im stworzyć zespół muzyczny! Od lojalnej przyjaźni czwórki już tylko krok do harmonijnie brzmiącego kwartetu muzycznego. Ta metaforyka - harmonii

\footnotetext{
${ }^{3}$ Jeszcze bardziej widocznie objawia się to $\mathrm{w}$ (epigramatycznej i narracyjnej) bajce zwierzęcej, wywiedzionej od starożytnego brzydala Ezopa; zwierzęta są tu maskami określonych ludzkich typów, a opisane relacje między nimi stanowią satyrę na stosunki międzyludzkie - zarówno te aktualnie portretowane, jak i na odwiecznie powtarzalne cechy człowieczego gatunku (Abramowska 1991). Sposób ujęcia zwierzęcych postaci wynika w dużej mierze z ludowego rodowodu bajki. O tym ważnym, często niedocenianym lub zgoła pomijanym aspekcie omawianego gatunku piszą inspirująco autorzy rozpraw pomieszczonych w tomie Bajka zwierzęca w tradycji ludowej i literackiej, 2011, Wróblewska V., Mianecki A. (red.).
} 
kilku elementów, wynikającej ze zgodnej współpracy, z poskromienia własnego temperamentu i egoizmu na rzecz dobra wspólnoty (tu: artystycznej, wykonawczej, muzycznej) narzuca się w interpretacji Muzykantów z Bremy bardzo sugestywnie i w naturalny sposób, a objawia się zarówno na poziomie litery, jak i ducha opowieści. Uczłowieczenie (a może pozorne uczłowieczenie? - zwierzęta po ludzku mówią i śpiewają, ale zachowują swoją zwierzęcą naturę) jest zabiegiem dokonanym przez Grimmów niezwykle konsekwentnie: począwszy od nadania zwierzętom umiejętności rozumienia słowa, poprzez obdarzenie ich zdolnością odczuwania, aż do ukazania ich wzajemnych relacji jako empatycznych, bezinteresownych, a prowadzących do uprawiania, najpierw chaotycznie i żywiołowo, potem zaś harmonijnie i pięknie, wspólnej, bezinteresownej sztuki. Autorzy tymi zabiegami nadają zwierzętom godność, sugerując, że razem mogą one tworzyć wspólnotę wyższego rzędu, zarówno społeczną, jak i artystyczną.

Polska badaczka literatury, ujmowanej w perspektywie ekokrytycznej, tak pisze o problemie zmieniającego się historycznie podejścia do zwierząt i do antropocentryzmu:

dekonstruowanie granicy między człowiekiem a zwierzęciem i zmiany w portretowaniu zwierząt, będące tego konsekwencją, prowadzą do ukazywania wiążących emocjonalnie relacji ludzi i zwierząt, dzięki którym zwierzę staje się kimś bliskim, istotą pośredniczącą, graniczną w świecie ludzi i przyrody. Postacie zwierzęce dotyczą najczęściej tych żyjących blisko człowieka, a nie wyobrażonych, którym albo bezpośrednio użycza się głosu do reprezentacji zwierzęcych problemów, jak w konwencji baśni, albo opowiada się o ich losie bez nadrzędnej funkcji alegoryzacji czy symbolizacji ludzkiego świata. Antropomorfizacja staje się okazją do pokazania zwierzęcych charakterów, (...) z którymi o wiele więcej łączy człowieka niż wcześniej sądzono (Barcz 2016, 14).

Czytając prostą baśń niemieckich mitografów i zbieraczy dawnych legend, można odnieść wrażenie, że nadrzędną intencją autorów nie było modelowe ukazanie stosunków międzyludzkich przez nakreślenie perypetii zwierząt. Chodziło im raczej o przekazanie (w najbardziej podstawowej wersji) opowieści naświetlającej moralne aspekty współistnienia ludzko-zwierzęcego i rozważenie problemów takich, jak starość, odrzucenie i bezduszność, którym zaradzić mogą dobroć, wdzięczność i wierność. W Muzykantach z Bremy scharakteryzowany został stosunek ludzi do zwierząt, zwierząt do ludzi i wreszcie - scharakteryzowane zostały obie te grupy: braci większych i mniejszych. I podczas gdy czworonożni czy upierzeni domownicy, mieszkańcy obór, stodół czy kurników to istoty pracowite, prostolinijne w stosunku do świata i przede wszystkim szczere, ludzie zachowują się różnie. Są może nie całkiem źli i zawistni, okrutni i chciwi, ale zawsze kierują się swoim wąsko pojętym interesem i małostkowym egoizmem jako wręcz prawem. Taki „podział wartości”, w nie najlepszym świetle stawiający ludzki gatunek, jest utrwaloną wizją baśniową, o czym świadczyć może choćby wielka popularność motywu, obecnego także i w baśni 
Grimmów. To wątek „zwierząt w zbójeckiej chacie”, pojawiający się w opowieściach hinduskich, ale rozpowszechniony także w całej Europie w licznych baśniach o zwierzętach domowych.

Są to zwykle kogut, kot, pies i osioł albo koń. (...) gnębione przez właściciela opuszczają jego podwórze i ruszają w świat. Z nadejściem nocy towarzystwo to znajduje schronienie w chacie należącej do zbójców, (...) upiorów albo diabła. Gdy właściciel chaty wraca, zwierzęta rzucają się na niego z takim wrzaskiem i hałasem, machaniem skrzydłami i tupaniem, że ten bierze nogi za pas, sądząc, że spotkał się z jakimś strasznym smokiem. Wtedy zwierzęta siadają do zastawionego stołu albo znajdują zakopane w chacie skarby (Kopaliński 1985, 1346) ${ }^{4}$.

Z opowieści tej wynika, że zwierzęta są na ogół dobre - ludzie na ogół źli; to zwierzęta demaskują zbójców i przeganiają samego diabła - ludzie się tylko ich boją. Zwierzęta żyją, walczą i śpiewają - ludzi najcelniej reprezentuje rakarz, myślący wyłącznie w kategoriach zysku i wygody.

Ta banalna wykładnia wydaje się najbliższa intencjom autorów i najbardziej zgodna z potocznym doświadczeniem. Podobnie ujął ów motyw Wacław Sieroszewski w bajce pt. Inwalidzi (1910) i Andrzej Sapkowski w opowiadaniu Muzykanci (2000), tym samym tropem interpretacyjnym poszli autorzy licznych animacji (m.in. radzieckiej, japońskiej i hiszpańskiej), powstałych na kanwie klasycznej baśni braci Grimm. Wiernie trzyma się też pochwalnej dla zwierząt, a krytycznej wobec ludzi, interpretacji losów muzykantów fabularna adaptacja filmowa, nakręcona w Niemczech w 2009 roku.

Praca artystki Katarzyny Kozyry Piramida zwierzat, eksponowana w 1993 roku w warszawskiej Zachęcie, w zamierzeniu autorki miała zwrócić uwagę odbiorców na problem okrucieństwa wobec zwierząt, jednak w powszechnym odczuciu sama to okrucieństwo obrazowała i reprezentowała. Pytania o sposób zabicia wypchanych przez autorkę zwierząt, ustawionych na sobie w charakterystycznym układzie, przypominającym słynną rzeźbę z Bremy, postawioną na pamiątkę baśniowej opowieści; o to, ile zadano im cierpienia i jak artystka zdobyła ich ciała na potrzeby swojej instalacji; o to, co mówią wypchane zwierzęta swoją obecnością w przestrzeni muzealnej - towarzyszyły wystawie pracy przez cały czas jej trwania. O etycznych aspektach tego przedsięwzięcia i o daremnym trudzie dania jednoznacznej odpowiedzi, o sensie podobnych do pracy Kozyry działań pisała kilkakrotnie i szczegółowo Dorota Łagodzka, krytyczka, specjalizująca się w problematyce tzw. „sztuki zwierzęcej” (Łagodzka 2014; Łagodzka 2015).

W dyskusji o granicach ingerencji człowieka w świat zwierzęcy sam podmiot zainteresowania, czyli zwierzęta, w reprezentatywnych dziełach plastycznych najczęściej milczą; mówią, swoim-nieswoim, ale jednak jakimś

${ }^{4}$ Julian Krzyżanowski zwraca uwagę na schematyczną budowę opowieści o zwierzętach w zbójeckiej chacie, składa się ona z trzech części: (I) Wyprawy w świat, (II) Nocy w chacie oraz (III) Zakończenia, czyli triumfu zwierząt (Krzyżanowski 1962, 60). Maria Fryczowa podkreśla „azjatycki trzon” bajki i zarazem jej ogromną popularność również w polskiej kulturze ludowej (Fryczowa 1960). Ryszard Nycz zaś zwraca uwagę, że Władysław Stanisław Reymont konstrukcję swej późnej powieści pt. Bunt oparł na schemacie bajki „zwierzęta w chacie” (Nycz 1974, 76). Żadna jednak z przywołanych analiz nie dotyczy problemu „muzyczności”. 
głosem tylko w literaturze. „Zapomniany język” (Fromm 1977) snów, baśni i mitów odtwarza i tłumaczy tylko liryczne czy narracyjne słowo.

Autorem refleksji na temat stosunku człowieka generalnie do przyrody, a do zwierząt w szczególności, wplecionych w moje streszczenie fabuły baśni o muzykantach z Bremy, jest Czesław Miłosz. Wybitny poeta był również świetnym tłumaczem i interpretatorem poezji światowej; jego uwagi o antropomorfizacji i animalizacji pochodzą z czasów poprzedzających narodziny animal studies jako dziedziny humanistyki współczesnej, zawierają jednak przeczucie i podświadomie wyrażoną potrzebę powstania tej gałęzi wiedzy. Wiedzy o zwierzęciu, a więc o człowieku; najgłębiej potrzebnej, coraz bardziej niezbędnej. Reprezentowana w poezji od zawsze, nie powszechna, ale wyrazista, postawa współczucia wobec zwierząt i ich cierpień, ma źródła emocjonalne i rozumowe. Pamiętał o tym Miłosz, przekładając i komentując wiersze o „zwierzętach i ich ludziach”. Po ich lekturze i przemyśleniu zrodzić się musi wniosek całkiem oczywisty i fundamentalny: miarą człowieczeństwa jest nasz stosunek do ożywionej przyrody, a do zwierząt nas otaczających przede wszystkim. Nie różnimy się od nich aż tak bardzo i nie możemy też wykluczyć, że odwieczne pytania o duszę nieśmiertelną mają szerszy niż tylko ludzki zakres.

Wyjątkowość Muzykantów z Bremy polega na podjęciu trudnych i bardzo zasadniczych rozważań nad tym, czym i czy tak naprawdę różnimy się od kopytnych, łownych, udomowionych czy też upierzonych. Czy słowo „zwierzę”, przez Arystotelesa i stoików przeciwstawiane pojęciu człowieczeństwa, znaczy dziś to samo co tysiąc lat temu? Czy nie pora na zmianę rozumienia jego sensu? I na nowe rozumienie słowa "człowiek"? Od czasu powstania pism Michela Foucaulta i Giorgio Agambena „człowieczeństwo” i „zwierzęcość” bywają inaczej już traktowane i interpretowane (Ładyga, Włodarczyk 2015, 8-10).

Warto pamiętać, że w dawnej baśni, w której głos (mówiony i śpiewany) oddany został skromnym, domowym zwierzętom, problem granic człowieczeństwa i wzajemnych stosunków ludzko-zwierzęcych został postawiony śmiało i bezkompromisowo. I jednocześnie z pewną nadzieją, że zakończenie „wielkiego podzielenia” jest możliwe w obszarze, w którym największym ideałem jest zgoda i harmonia: na polu życia wspólnotowego, inspirowanego sztuką muzyczną.

\section{Bibliografia}

Abramowska Janina, 1991, Polska bajka ezopowa, Poznań.

Bajka zwierzęca $w$ tradycji ludowej i literackiej, 2011, Wróblewska V., Mianecki A. (red.), Torun.

Barcz Anna, 2016, Realizm ekologiczny. Od ekokrytyki do zookrytyki w literaturze polskiej, Katowice. 
Beaumarchais Pierre, 1951, Wesele Figara, Żeleński Boy T. (przeł. i wstęp), Warszawa.

Caillois Roger, 1967, Odpowiedzialność i styl. Eseje, Błoński J., Lisowski J., Dolatowska K. (przeł.), Warszawa.

Fromm Erich, 1977, Istota języka symbolicznego, w: Zapomniany język. Wstęp do rozumienia snów, baśni i mitów, Marzęcki J. (przeł.), Toeplitz K.T. (wstęp), Warszawa.

Fryczowa Maria, 1960, Zwierzęta w chacie. Analiza polskiej bajki zwierzęcej, „Lud”, t. 45.

Grimm Jacob, Wilhelm, 1982, Baśnie, Bielicka E., Tarnowski M. (przeł.), Warszawa.

Kaźmierczak Zbigniew, 2013, Ludzie starzy i humaniści we wspólnocie bezużytecznych, w: Starość. Doświadczenie egzystencjalne, temat literacki, metafory kultury, Ławski J. (wstęp), Janicka A., Wesołowska E., Zabielski Ł. (red.), Białystok.

Kopaliński Władysław, 1985, Słownik mitów i tradycji kultury, Warszawa.

Kostecka Weronika, 2013, Od aksjologii do estetyki. Grimmowskie ujęcia grozy i okrucieństwa $w$ „Kinder - Und Hausmärchen” jako inspiracja dla twórców współczesnej fantastyki, w: Grimm: potęga dwóch braci. Kulturowe konteksty „Kinder - Und Hausmärchen”, Kostecka W. (red.), Warszawa.

Krzyżanowski Julian, 1962, Polska bajka $w$ układzie systematycznym, t. 1, Wrocław.

Ładyga Zuzanna, Włodarczyk Justyna, 2015, Wstęp, w: Po humanizmie. Od technokrytyki do animal studies, Ładyga Z., Włodarczyk J. (red.), Gdańsk.

Łagodzka Dorota, 2014, Śmierć zwierząt w sztuce współczesnej na przykładzie „Piramidy zwierzą" Katarzyny Kozyry, w: Śmierć zwierzęcia. Współczesne zootanatologie, Kotyczka M. (red.), Katowice.

Łagodzka Dorota, 2015, Wystawy sztuki zwierzęcej w Polsce od końca lat dziewięćdziesiątych XX wieku do dziś, w: Zwierzęta i ich ludzie. Zmierzch antropocentrycznego paradygmatu?, Barcz A., Łagodzka D. (red.), Warszawa.

Miłosz Czesław, 1994, O przyrodzie, w: Wypisy z ksiąg użytecznych, Kraków.

Nycz Ryszard, 1974, Dwa pejzaże Reymonta, „Pamiętnik Literacki”, z. 3.

Pawełczyk Kamila, 2013, Starość w czasie i przestrzeni. Modele starości na wybranych przykładach kulturowych, w: Starość. Doświadczenie egzystencjalne, temat literacki, metafory kultury, Ławski J. (wstęp), Janicka A., Wesołowska E., Zabielski Ł. (red.), Białystok.

Skrzypczak Magdalena, 2013, Unurzane w smacznym okrucieństwie. Estetyka groteski i makabreski w wybranych baśniach braci Grimm, w: Grimm: potęga dwóch braci. Kulturowe konteksty "Kinder - Und Hausmärchen”, Kostecka W. (red.), Warszawa. 


\section{O Autorce:}

Joanna Maleszyńska pracuje w Zakładzie Poetyki i Krytyki Literackiej Instytutu Filologii Polskiej Uniwersytetu im. Adama Mickiewicza w Poznaniu oraz w Centrum Badań nad Teatrem Muzycznym w UAM. Do jej szczególnych zainteresowań badawczych należą: literatura i kultura europejska, poetyka i retoryka, librettologia i historia musicalu oraz wszelkie rodzaje związków literacko-muzycznych. 
